${ }^{3}$ Haynes RM, Bentham CG. The effects of accessibility on general practitioner consultations, out-patient attendances and inpatient admissions in Norfolk, England. Soc Sci Med 1982;16: 561-9.

${ }^{4}$ Pugh E, Henson E. Relations between acceptance of measles and pertussis immunisation. Br Med $J$ 1985;291:638, 1206.

James J, Clark C, Rossdale M. Improving health care delivery in an inner-city well baby clinic. Arch Dis Child 1986;61:630. ${ }^{\circ}$ Lingam S, Miller CL, Pateman J. Role of an immunisation
advisory clinic. $B r$ Med $J$ 1986;292:939-40.

Correspondence to Dr R Hall, Department of Community Medicine, Clwyd Health Authority, Preswylfa, Hendy Road, Mold, Clwyd CH7 $1 \mathrm{PZ}$.

Accepted 8 August 1988

\title{
Platelet phenolsulphotransferase activity and 'abdominal migraine'
}

\author{
C GIBB,$*$ V GLOVER,${ }^{*}$ N GILBERTSON, $\dagger$ D BENTLEY, $\ddagger$ AND M SANDLER $*$ \\ ${ }^{*}$ Bernhard Baron Memorial Research Laboratories, Queen Charlotte's Hospital, London, †Department of \\ Paediatrics, Ealing, and $¥$ Department of Child Health, Royal Postgraduate Medical School, London
}

SUMMARY Low platelet phenolsulphotransferase activity has been reported in adult patients with dietary sensitive migraine. Platelet activity of this enzyme was therefore measured in children having 'abdominal migraine' with probable dietary trigger and in controls. No significant difference was found in activity between the two groups. There was no significant correlation between platelet phenolsulphotransferase activity and age.

'Abdominal migraine' in children is characterised by
recurrent central abdominal pain, and is typically
associated with pallor and with gastrointestinal
symptoms such as anorexia, nausea, or vomiting.
Despite the term being clearly self contradictory, as
migraine comes from the Latin 'hemicrania' mean-
ing '(pain in) the half of the head', it has become
hallowed by usage, and reflects the suggestion that
there is a relationship with common or classical
migraine. Indeed, a positive family history of cranial
migraine is often taken as a diagnostic criterion and,
although not conclusive, evidence strongly suggests
that there is a relationship between 'abdominal
migraine' and common or classical migraine. ${ }^{1}$ As
there is, as yet, no diagnostic laboratory test for
migraine, diagnosis is purely clinical, and it remains
uncertain whether common pathophysiological
mechanisms underlie the two conditions.

In many cases it is thought that attacks of 'abdominal migraine' can be provoked by articles of diet, with the list of foods implicated being very similar to those suggested as being linked to dietary cranial migraine. In particular citrus fruit, cheese, and chocolate are often cited as provoking agents. ${ }^{2} 3$ Adult migraine patients who believe that dietary factors can provoke their attacks have significantly lower mean platelet phenolsulphotransferase $\mathrm{P}$ and phenolsulphotransferase $M$ activity than patients with migraine not caused by diet or controls. ${ }^{45}$ It therefore seemed of interest to measure platelet phenolsulphotransferase activities in a group of children suffering from 'abdominal migraine' with probable dietary trigger.

\section{Patients and methods}

Platelet suspensions in sucrose were prepared from blood collected from a group of patients attending Ealing Hospital as outpatients $(n=21 ; 10$ boys, 11 girls) and from a group of controls $(n=13$; six boys, seven girls). The major criteria used for making a diagnosis of 'abdominal migraine' were recurrent central abdominal pain (more than three attacks in not less than three months) accompanied by pallor, nausea or vomiting, or both, and a positive family history of migraine. At the time of study patients and controls were outside an attack and drug free. The mean (SD) age of patient group was $8.8(2.5)$ years and of the control group 7.9 $(3 \cdot 2)$ years with a range from 3-13 years. Platelet samples were also collected from a group of adult controls $(n=16)$ with a mean (SD) age of $36 \cdot 6(13.2)$ years with a range from 22 to 60 years.

Phenolsulphotransferase activity was assayed using phenol (final concentration $10 \mu \mathrm{mol} / \mathrm{l}$ ) and tyramine (final concentration $130 \mu \mathrm{mol} / \mathrm{l}$ ) as substrates for phenolsulphotransferase $\mathrm{P}$ and phenolsulphotransferase $\mathrm{M}$ respectively. ${ }^{6}$ Platelet samples, prepared as described previously, ${ }^{4}$ were used as enzyme source.

\section{Results}

No significant difference was found in either platelet 
Table Mean (SEM) platelet phenolsulphotransferase $P$ and $M$ activities in children with abdominal migraine and in controls

\begin{tabular}{lll}
\hline & \multicolumn{2}{l}{$\begin{array}{l}\text { Specific activity } \\
\text { (nmol/mg protein/10 min) }\end{array}$} \\
\cline { 2 - 3 } & $\begin{array}{l}\text { Phenolsulpho- } \\
\text { transferase } P\end{array}$ & $\begin{array}{l}\text { Phenolsulpho- } \\
\text { transferase } M\end{array}$ \\
\hline Patients $(\mathrm{n}=21)$ & $0.037(0.006)$ & $0.382(0 \cdot 025)$ \\
Controls $(\mathrm{n}=13)$ & $0.031(0 \cdot 007)$ & $0.298(0.043)$ \\
\hline
\end{tabular}

phenolsulphotransferase $\mathbf{P}$ or phenolsulphotransferase $M$ activity between patients and controls (table). No significant correlation was found between platelet phenolsulphotransferase activity and age $(r=0.09)$.

\section{Discussion}

The condition to which the clinical label of 'abdominal migraine' has been applied does have certain characteristic features in common with 'cranial' migraine in terms of family history, symptomatology, and triggering factors. The fundamental difference between the two conditions is in the location of the perceived pain and, as discussed earlier, this fact renders the label etymologically unsound. The justification for its continued use would be some firm physicochemical confirmation that a relationship does exist between 'abdominal migraine' in childhood and common or classical migraine in later life. The lack, to date, however, of any diagnostic laboratory test for migraine makes this confirmation difficult.

The finding that adult patients with migraine caused by diet have lower mean platelet phenolsulphotransferase activity than those with migraine not caused by diet or controls suggested the possibility that a similar biochemical deficiency might exist in children suffering from 'abdominal migraine' with probably dietary trigger. The results of this study, however, fail to show any such common biochemical deficiency. Even so, interpretation of these negative results must be made with caution because of the relatively small numbers of patients investigated. With this reservation, we would state that, at least, no further evidence has been educed pointing to a common aetiology of so called abdominal migraine and the more firmly established 'cranial' variety.

We thank the Ministry of Agriculture, Fisheries and Food who defrayed the salary of CG. Mrs B Davies, of the department of haematology, Ealing Hospital, kindly prepared the platelet samples.

\section{References \\ ${ }^{1}$ Wilson J, ed. Migraine in childhood. Oxford: Medicine Publi- shing Foundation, 1983. \\ ${ }^{2}$ Egger J, Wilson J, Carter CM, Turner MW, Soothill JF. Is migraine food allergy? A double-blind controlled trial of oligoantigenic diet treatment. Lancet 1983;ii:865-9. \\ ${ }^{3}$ Glover V, Littlewood J, Sandler M, Peatfield R, Petty R, Rose FC. Dietary migraine: looking beyond tyramine. In: Rose FC, ed. Progress in migraine research 2. London: Pitman, 1984: 113-9. \\ ${ }^{4}$ Littlewood J, Glover V, Sandler M, Peatfield R, Petty R, Rose FC. Phenolsulphotransferase deficit in dietary migraine. Lancet 1982;i:983-6. \\ 5 Soliman H, Pradalier A, Launay J-M, Dry J, Dreux C. Decreased phenol and tyramine conjugation by platelets in dietary migraine. In: Rose FC, ed. Advances in headache research. London: John Libbey, 1987:117-21. \\ 6 Bonham Carter SM, Rein G, Glover V, Sandler M, Caldwell J. Human platelet phenolsulphotransferase $M$ and $P$ : substrate specificities and correlation with in vitro sulphoconjugation of paracetamol and salicylamide. $\mathrm{Br} J$ Clin Pharmacol 1983;15:323-30.}

Correspondence to Professor M Sandler, Department of Chemical Pathology, Queen Charlotte's and Chelsea Hospital, Goldhawk Road, London W6 0XG.

Accepted 11 August 1988

\section{Epidemiology of rheumatic heart disease}

\section{A IMAMOGLU AND S OZEN* \\ Departments of Paediatrics, Ankara University and *Hacettepe University, Turkey}

SUMMARY We compared the incidence of rheumatic heart disease in elementary schoolchildren from low and high socioeconomic groups; children from one of the schools were rescreened 10 years later. The results showed that the incidence of rheumatic heart disease was significantly higher in low socioeconomic group but it is gradually declining.
Rheumatic carditis is one of the most important preventable heart diseases in children. Although in developed countries there is a dramatic decline in the incidence of rheumatic fever and rheumatic heart disease, they still remain a leading cause of heart disease in developing countries such as Turkey. ${ }^{12}$ This difference is reported to be related to factors such as crowding, nutrition, hygiene, urban-rural residence, and access to medical care. ${ }^{2-4}$ 